\title{
Effects of Seasonal Variation on Informal Waste Collection in Ibadan, South-west Nigeria
}

\author{
Bolanle Wahab ${ }^{1} \&$ Bayonle Ola ${ }^{2}$ \\ ${ }^{1}$ Department of Urban and Regional Planning, Faculty of Environmental Design and Management, University of \\ Ibadan, Ibadan, Nigeria \\ ${ }^{2}$ Department of Urban and Regional Planning, University of Ilorin, Ilorin, Nigeria \\ Correspondence: Bolanle Wahab, Department of Urban and Regional Planning, Faculty of Environmental \\ Design and Management, University of Ibadan, Ibadan, Nigeria. Tel: 234-807-991-7354. E-mail: \\ bolanle_wahab@yahoo.com
}

Received: February 18, 2018

Accepted: March 1, $2018 \quad$ Online Published: March 30, 2018

doi:10.5539/ep.v7n1p36

URL: https://doi.org/10.5539/ep.v7n1p36

\begin{abstract}
Despite the active participation of informal waste collectors (IWCs) in waste management in Ibadan, south-west Nigeria, a major observed challenge to effective operation of this group of workers is the variation in the seasons of the year and their accompanying weather futures. This study investigated the effects of seasonal changes on the types and volume of waste handled by the informal waste collectors, level of patronage and income earned in the five municipal local government areas of Ibadan. A cross-sectional survey approach was adopted and both primary and secondary data were sourced. Through questionnaire survey and field observations, data were collected from 253 informal waste collectors operating in the study area. Descriptive statistics (frequencies and percentages) and inferential statistics (ANOVA) were used in analysing the data obtained from the field work. The study established that the types and volume of waste collected and income earned by the informal waste collectors varied from season to season. Patronage of the informal waste collectors was found to be reduced by about $25 \%$ in the dry season owing to less volume of waste generated and increased burning. The low patronage reduced the income by about $25 \%$ on average. The implications of this are that the job security of IWCs is threatened and increased burning of waste increases the atmospheric carbon content, which depletes the ozone layer and consequently results in global warming. The study, therefore, recommended financial and technical assistance to the waste collectors by either government or non-governmental organisations to establish small waste merchandising business to cater for the period of low patronage.
\end{abstract}

Keywords: Ibadan, informal waste collectors, level of patronage, seasonal variation

\section{Introduction}

Informal waste collection is an economic venture which involves using unorthodox means of waste collection and transportation such as cart, wheelbarrow, head pan or basket, to collect, transport and dispose of household waste for a fee. Studies have shown the effectiveness of informal waste collectors (IWCs) in waste management despite the rudimentary nature of their operation (Zelalem, 2006; Slackman, 2009; Ola, 2016). They have been especially responsible for waste collection in the high-density neighbourhoods of cities, where formal collection is virtually non-existent (Jerie; and Tevera, 2014; Wahab and Ola, 2016). Despite some level of effectiveness observed in the activities of the IWCs in waste management, a major challenge to effective operation of this group of workers is the variation in the seasons of the year and the accompanying weather futures.

Seasons on the earth surface are the result of yearly revolutions of the earth around the sun in combination with the tiltiture of the earth creating differences in heat distribution (Kirchhoff, da Silva, Browell, 1990). During summer (dry season) in the northern hemisphere, the weather is at its warmest because the sun is directly overhead at the Tropic of Cancer, while in winter (rainy season), in the northern hemisphere, it is colder because the sun is over the Tropic of Capricorn (Kirchhoff, da Silva, Browell, 1990). Thus, the dry season is a yearly period of low rainfall, especially in the tropics. The weather in the tropics is dominated by the tropical rain belt which moves from the northern to the southern tropics and back over the course of the year (Rennell, 2007). The tropical rain belt lies in the southern hemisphere roughly from October to March. During this period, the northern tropics have a dry season with sparser precipitation and days are typically sunny throughout. From April to September, the rain belt lies in 
the northern hemisphere and the southern tropics have their dry season. Under the Köppen climate classification for tropical climates, a dry season month is defined as a month when average precipitation is below 60 millimetres (Rennell, 2007). Because the dry season has low humidity, the lack of water effects a slight shift in consumption pattern of the people, as less leaf-related food and fruits are consumed. Usually, there is a higher concentration of people in the urban centres in dry season, as agricultural activities are virtually impossible without irrigation. These make some farmers to move into cities, creating hubs of higher population density and, consequently, more waste is generated. However, the dry season offers more opportunity to residents to burn their waste and this reduces the quantity of waste available for collection.

The rain belt reaches roughly as far north as the Tropic of Cancer and as far south as the Tropic of Capricorn. Near these latitudes, there is one wet season and one dry season annually (Omigbodun, 2013). At the equator, there are two wet and two dry seasons, as the rain belt passes over the equator twice a year, once moving north and once moving south. Between the tropics and the equator, locations may experience a short wet and a long wet season; and a short dry and a long dry season. However, local geography may substantially modify these climate patterns (Omigbodun, 2013).

A close look at the literature revealed that less research efforts have been focused on investigating how the changes in seasons of the year affect the activities of the IWCs with reference to waste collection, transportation and disposal as well as patronage. Rather, many authors have concentrated on analysing the effects of seasonal variation on the types and volume of municipal or domestic waste generated (Rhyner, 1992; Gómez et al., 2009; Boldrin, Christensen, 2009; Denafas et al., 2010; Mshelia, 2015). This is the motivation for this study, which attempted to fill this gap by looking at the effects of seasonal variations on the activities of IWCs, focusing on Ibadan, a large conurbation and a regional capital with a significant number of active informal waste collectors.

\section{Literature Review}

The interplay of climatic features gives rise to seasons. Therefore, the phenomenon of climate change greatly influences the occurrence and variations of the seasons. Much of the waste generated in rural and urban communities in Nigeria is either burnt or left to rot and this constitutes a significant source of the country's contribution to greenhouse gas emissions (Uwejamomere, 2003; Wahab, 2009). Gases that trap heat in the atmosphere are often called greenhouse gases. According to the United States Environmental Protection Agency (USEPA) (2012), some of these gases that are emitted to the atmosphere through the burning of solid waste, among other human activities, are carbon dioxide, methane, nitrous-oxide, as well as fluorinated gases. These gases are ozone-depleting substances and are sometimes referred to as high global warming potential gases. The consequences of ozone depletion are the various environmental hazards (like flood, tsunami, and fire outbreak) witnessed in virtually every part of the world in the last few decades (IPCC, 2017; USEPA, 2017). The city of Ibadan has experienced annual flood disaster from 2011 to 2017 and fire incidents in different parts of the city, with indiscriminate waste dumping and burning being a causal factor. The intensity of these hazards in recent times calls for greater attention by policy makers and researchers.

Enete (2010) argues that climate change could result in changes in temperatures, cloud cover, rainfall patterns, wind speeds and storms, which could all impact the development and operation of waste management facilities. The time scales for climate change and waste management are similar. For instance, landfill sites can be operational for decades and can still remain active for decades after their closure. There is, therefore, a need to consider potential changes in waste management over significant timescales and respond appropriately. In a report by USEPA (2016), waste reduction through recycling of about 35 per cent of waste is estimated to reduce greenhouse gas emissions by 11.4 million metric tons of carbon equivalent (MTCE, the basic unit of measure for greenhouse gases) over landfilling the same material. The report further noted that waste prevention also makes an important difference: by cutting the amount of waste that humans generate by just 5 per cent, greenhouse gas emissions can be reduced by another 10.2 million MTCE. United Nations Environment Programme (UNEP) (2010) observes that the waste management sector is in a unique position to cease to be a source of emission of greenhouse gases (GHG) overall to become a major contributor to the reduction of greenhouse gas emission.

Although waste management in developing countries have been largely characterized by municipal collection and formal private sector participation, the inability of the two actors to achieve a reasonable collection rate gave room for waste to accumulate in the environment, thereby threatening the public health and partly inducing negative climate change. Attempt to fill the vacuum created in waste management led to the emergence of IWCs, who have been active in waste collection in Nigeria and in some developing countries, such as Ethiopia, India, Kenya, Brazil, and South Africa.

The volume and type of waste generated in Nigeria, as in other countries of the world, are influenced by seasonal 
variation. In his study of Oyo, Nigeria, Afon (2007) found that 1,093 tons of waste was generated in the month of July (wet season), while 774 tons was generated in the month of February (dry season). Leaves were the dominant waste in the dry season, while paper was the dominant waste in the wet season. The preponderance of paper in the wet season can be explained by the fact that paper is mostly used to wrap cold palp, bean cake (akara), mossa, moin-moin and other local snacks, such as puff-puff, for consumption owing to the shortage in the supply of leaves. The wet season is the growing period for leaves, while they are harvested in the dry season. In the Mubi metropolis, Nigeria, according to Mshelia (2015), 26,378 households have a daily waste generation of $1435.6 \mathrm{~kg}(2.7 \mathrm{~kg} /$ household/day $)$ in the wet season and $1658.5 \mathrm{~kg} /$ day $(3.1 \mathrm{~kg} /$ household $/$ day $)$ in the dry season. While garbage is generated the most in the wet season $(432.5 \mathrm{~kg} /$ day $)$, ashes are generated the most in the dry season $(481.1 \mathrm{~kg} /$ day $)$.

This seasonal variation has been found to affect the volume and type of waste evacuated by IWCs in a number of countries. Pacific Consultants International (PCI) (2008) note that, in Manila, Philippines, ash/earth and vegetable were the dominant wastes collected by the IWCs in the wet season, while paper and plastic waste predominated the dry season. While the IWCs collected about 4000 tons of waste monthly in the wet season, some 3100 tons were collected in the dry season (PCI, 2008). However, despite the variation in the volume of waste collected by the IWCs, the author does not give the variation in the income in both seasons, as the study only revealed a daily earning of U.S\$5-10 by the IWCs in the city. Kamran et al. (2015) claim that, in Lahore, Pakistan, the average weekly waste collection by the IWCs in the wet and dry seasons was 1200 tons and 1050 tons, respectively. The dominant wastes in the wet and dry seasons were vegetable and rubber, respectively. The study, however, does not give information on the income from waste collection or the variation in the income. No variation in the volume and types of waste collected by the IWCs was also found in Porto Alegre, Brazil, as reported by Gutberlet (2008) where the IWCs served 79\% of the city's 1.1 million population and evacuated 100 tons of waste monthly. The dominant wastes were vegetable and paper. The waste collectors earned about US\$300 a month, which was twice the minimum wage in Brazil. The IWCs in Egypt, known as Zabaleen, collected 2,700 tons of mainly food waste per day in the wet season, nearly $50 \%$ of the Cairo's daily total waste of 6,000 tons (Slackman, 2009). But a slightly higher volume of waste (2,817 tons) was collected in the dry season. The dominant wastes collected in the dry season were paper, plastic and glass (Slackman, 2009). The departure from the situations in other cities earlier reviewed and the recyclable nature of the dominant wastes collected in Egypt in the dry season may be attributed to the well-organized waste recycling activities of the Zabaleens. As earlier observed by Fahmi and Keith (2006), the Zabaleen recycled as much as $85 \%$ of the waste they collected. However, the variation in income of the Zabaleens was not reported by any of the authors. Apart from the specific shortcomings identified in the previous works, none of the studies ventured into identifying the effects of seasonal variation on the waste transportation and disposal by the IWCs. This study filled the observed gap.

\section{Study Area and Methodology}

Ibadan is located between longitude $7^{0} 20^{1} \mathrm{E}$ and $7^{0} 40^{1} \mathrm{E}$ and latitude $3^{0} 35^{1}$ and $4^{0} 10^{1}$. It is $145 \mathrm{~km}$ north-east of Lagos and 345km south-west of Abuja, the Federal capital (Figs. 1, 2 and 3). Ibadan enjoys the West African monsoonal climatic type marked by two distinct seasons. The rainy season falls between March and October, when the moist monsoonal wind from the Atlantic Ocean blows over the region. The dry season falls between November and February owing to the influence of the dry, dust-laden north-east trade winds from the Sahara Desert (Oguntoyinbo, 1994). The mean annual rainfall in Ibadan recorded between 1911 and 1988 was $1258.9 \mathrm{~mm}$. However, monthly and yearly values of rainfall generally fluctuate. For instance, a value of $151 \mathrm{~mm}$ was recorded for the month of April, 1997, while the month of August, 2011 recorded 187.5mm (NMS, 2011, cited in Oyo State Government [OYSG], 2011). The mean temperatures are highest at the end of the harmattan (averaging $28^{\circ} \mathrm{C}$ ), that is, from the middle of January to the onset of the rains in the middle of March. Even during the rainfall months, average temperatures are relatively high, between $24^{\circ} \mathrm{C}$ and $25^{\circ} \mathrm{C}$, while annual fluctuation of temperature is about $6^{\circ} \mathrm{C}$ (OYSG, 2011).

The development of Ibadan has been influenced by traditional and colonial urbanization. The city's population in 1856 was about 60,000 and by 1890 it had increased to about 200,000. The population further grew to 627,379 in 1963, 1.2 million in 1991, and 2.6 million in 2006 (Afolayan, 1994; Olujinmi, 2009). Although the provisional result of the 2006 national population census gave the population of Ibadan as 2,555,893 (FRN, 2007), using $3.2 \%$ growth rate as recommended by the National Population Commission (NPC) (NPC, 2007), the 2017 population of Ibadan was estimated at about 3.4 million.

The increasing demographic figures of Ibadan have played a dominant role in the volume of waste generated in the city over the years. For instance, in the late 1960s and the early 1970s, the estimated solid waste generation 
rates for the inner city and the suburban districts of Ibadan were between 0.37 to $0.50 \mathrm{~kg} /$ capita/day and 0.53 $\mathrm{kg} / \mathrm{capita} /$ day, respectively (Maclaren International Ltd., 1970). In the 1980s, PAI Associates (1982) estimated the solid waste generation rate of $3.4 \mathrm{~kg} /$ household/day in the core areas, $3.2 \mathrm{~kg} /$ household/day in the suburbs and $3.3 \mathrm{~kg} /$ household/day in the whole city. This gave a per capita generation rate of $0.33 \mathrm{~kg} /$ day. Also, a study by Oluwande (1983) revealed a per capita waste generation of $0.42 \mathrm{~kg} / \mathrm{day}$ in the government reserved areas (GRAs), $0.38 \mathrm{~kg} / \mathrm{day}$ in the urban fringe and $0.35 \mathrm{~kg} / \mathrm{day}$ in the traditional areas. Sridhar et al. (1985) estimated $0.428 \mathrm{~kg}, 0.289 \mathrm{~kg}$ and $0.132 \mathrm{~kg}$ refuse per capita among families in high, middle and low socio-economic groups, respectively, in Ibadan; while the estimates by Ayorinde et al. (2010) put the daily per capita solid waste generation for Ibadan at $0.52 \mathrm{~kg}$.

The statutory body responsible for waste management in the city is the Oyo State Solid Waste Management Authority (OYOWMA) under the Ministry of Environment and Water Resources. The OYOWMA waste collection and disposal activities are complemented by private refuse companies (PRCs) licensed by the state government to undertake waste collection, particularly in the low-density residential areas of the city (Oyo State of Nigeria, 2013). There were 259 PRCs in 2013 (OYOWMA, 2013), which increased to 400 in 2016 (Hammed, Sridhar and Wahab, 2016). However, the combined activities of both the public actor (OYOWMA) and the organised private refuse contractors have not translated into effective waste management services in Ibadan, as only $10 \%$ of the $485,860,260 \mathrm{~kg}$ of solid waste generated annually in the city is evacuated (OYSWMA, 2012 cited in Hammed, Sridhar and Wahab, 2016). But, the informal private sector is found to be very active in solid waste management scheme of the city (Wahab and Ola, 2016).

\subsection{Methodology}

Data for this study were collected through questionnaire survey, field observations and actual measurement of waste volume. The questionnaire administration was carried out in the months of May (wet season) and December (dry season) in 2016. A pre-tested structured questionnaire was administered to 253 out of the 506 informal waste collectors identified in the five municipal local government areas of the city. The 90-item questionnaire was designed to obtain information on the types and volume of waste collected by IWCs in both dry and wet seasons in the city as well as how the seasons affect both the rate of patronage of the collectors and the collectors' income, among others. The questionnaire was prepared in English and administered by four trained field assistants who were graduates and could translate the questions into the native language of the respondents who did not understand English.

Questionnaire administration was conducted between 8 am and $6 \mathrm{pm}$ daily for six days from Saturday to Thursday. Completed copies of the questionnaire for each day were checked for any error or ambiguous responses. Hand-held balance scale was used by the trained research assistants to measure the volume of the waste collected by the IWCs over a seven-day period in both the wet and dry seasons. Through the cooperation and permission of the sampled informal waste collectors, the researchers also observed and sorted the waste collected by each collector over a seven-day period to determine the types and volume of waste collected. In the course of the field observation, photographs of waste scenes such as waste transportation and disposal of the waste handled by the sampled collectors were taken. All the 253 copies of the questionnaire administered were returned for analysis.

Data collected were analysed with the aid of the Statistical Package for Social Sciences (SPSS) software (Version 20) and presented using descriptive statistics in the form of frequency distribution of the types of waste collected and inferential statistics. Analysis of Variance (ANOVA) was employed to determine the statistical significance of the variations in the types and volume of waste collected by the IWCs. Ethical issues were given due consideration, as regard the purpose of the study, contents of the research instrument, acceptance of respondents' right to privacy, confidentiality of the data, and the informed consent and willingness of the respondents to answer questions.

\section{Results and Discussions}

This section discusses how variations in the seasons of the year affect the types and volume of waste collected by the informal waste collectors. The study location enjoys a short dry- and a long rainy season. Some $(60.1 \%)$ of the sampled informal waste collectors stated that seasonal difference affected their business, while $39.9 \%$ stated otherwise. Of those whose business was affected by seasonal difference, $42 \%$ indicated the wet season as the period they recorded more patronage, while $18.1 \%$ indicated the dry season. The IWCs handled $255 \mathrm{~kg}$ of waste in the wet season, compared to $203 \mathrm{~kg}$ in the dry season. The higher volume of waste generation during the wet season, as established by Afon's (2007) study, was observed to be responsible for the high demand for waste collection services in the wet season. 


\subsection{Types of Waste Collected in Wet and Dry Seasons}

Findings established that seasons had effect on the types of waste collected by the IWCs, as claimed by $80.2 \%$ of them. Table 1 shows the components found in the waste collected by the IWCs. The dominant wastes collected in the wet season were maize husk, $15.7 \%$; leaves, $14.2 \%$; human excreta, $11.9 \%$; fruits, $11.1 \%$; vegetables, 9.9\%; glass, $6.7 \%$; and others, $30.5 \%$. The dominant wastes collected in the dry season were polythene, $14.2 \%$; construction debris, $11.9 \%$; ash/dust, $10.3 \%$; textiles, $9.1 \%$; and others, $54.5 \%$ (Table 1). The wastes were generated by the households during the seasons. The dominant wastes collected in both seasons in Ibadan appear to conform to the pattern from other cities reviewed- Lahore (Pakistan), Porto Alegre (Brazil), Manilla (Philippines) - (PCI, 2008; Gutberlet, 2008; Kamran et al., 2015). This could be explained by the fact that the socio-economic development in Ibadan and those cities is level; hence, the preponderance of food (organic) waste. Variation in the types of waste collected in the dry and wet seasons was statistically significant, as the F value of the computed ANOVA was 12.99 at $\mathrm{p}=0.019$.

Table 1. Components of waste evacuated by informal waste collectors in the wet and the dry seasons

\begin{tabular}{lcrlcc}
\hline \multicolumn{7}{l}{ Types of Wastes in the Wet Season } & \multicolumn{5}{l}{ Types of Waste in the Dry Season } \\
\hline Wastes & Freq. & $\mathbf{\%}$ & Wastes & Freq. & \% \\
\hline Leaves & 36 & 14.2 & Dead Animals & 15 & 5.9 \\
Maize Husk & 40 & 15.7 & Polythene & 36 & 14.2 \\
Vegetables & 25 & 9.9 & E-waste & 17 & 6.7 \\
Fruits & 28 & 11.1 & Plastic & 21 & 8.3 \\
Human Excreta & 30 & 11.9 & Construction Debris & 30 & 11.9 \\
Textiles & 7 & 2.8 & Wood & 11 & 4.3 \\
Paper & 16 & 6.3 & Leaves & 15 & 5.9 \\
Polythene & 12 & 4.7 & Maize Husk & 5 & 2.0 \\
Glass & 17 & 6.7 & Vegetables & 9 & 3.6 \\
Plastic & 14 & 5.5 & Fruits & 11 & 4.3 \\
Ash/Dust & 6 & 2.4 & Human Excreta & 5 & 2.0 \\
Wood & 5 & 2.0 & Textiles & 23 & 9.1 \\
e-waste & 4 & 1.6 & Paper & 5 & 2.0 \\
Dead Animals & 6 & 2.4 & Ash/Dust & 26 & 10.3 \\
Construction Debris & 7 & 2.8 & Glass & 24 & 9.5 \\
Total & $\mathbf{2 5 3}$ & $\mathbf{1 0 0 . 0}$ & Total & $\mathbf{2 5 3}$ & $\mathbf{1 0 0 . 0}$ \\
\hline
\end{tabular}

Naturally, the availability of enormous quantities of crop residues (such as maize, yam, cassava, fruits of different types and vegetables) associated with the wet season, and the tendency for people to consume more during this period owing to the cheap prices of most of these agricultural residues usually lead to more waste generation and consequently high demand for waste service providers. Also, the difficulty in burning some of the wet waste within or around houses, as practised by some households during the period, made it imperative for them to require waste service providers. The preponderance of nylon or polythene (mostly from packaged water sachets and from consumed local food, such as àmàlà, füfú, iyán and èbà), glass (mostly broken bottles) and plastic in the dry season was as a result of social engagements and religious celebrations (Christmas and New Year) that normally characterized the period. Naturally, in Yoruba land (part of which is Ibadan), people prefer slating their social engagements (especially wedding, house-warming, annual meetings and development programmes by town unions and other indigenous organisations) for the dry season in order to avoid possible disturbance by rainfall and to enable farmers to participate, as they would have less to do on the farm.

\subsection{Volume of Waste Collected in the Wet and the Dry Seasons}

Table 2 summarizes the data generated from the field survey on the volume of waste collected by the informal waste collectors in both seasons. Analysis of the data for the wet season indicated that the amount of waste 
evacuated in a week by each of the sampled waste collectors ranged from $172 \mathrm{~kg}$ to $3400 \mathrm{~kg}$. Although some $(15 \%)$ evacuated $1,845 \mathrm{~kg}$ in a week, on average, a collector evacuated $255 \mathrm{~kg}$ per day, 1,786 kg per week, 7,905 $\mathrm{kg}$ per month and 94,860 kg per year. Putting all the 253 sampled informal waste collectors into consideration, it could be deduced that the sector was responsible for evacuating about $64,515 \mathrm{~kg}$ ( 64.5 tons) per day, 451,858 $\mathrm{kg}$ (452 tons) per week, 1,999,965 kg (2000 tons) per month and 23,999,580kg (24,000 tons) per year (Table 2). Applying these collection rates to the 506 IWCs enumerated in the study area revealed that the informal waste sector was responsible for evacuating during the wet season about $129,030 \mathrm{~kg}$ (129 tons) per day, 903,210 kg (903 tons) per week, 3,999,930 kg (3,999 tons) per month and 47,999,160 kg (47,999 tons) per year.

A comparison of the volume of waste evacuated in the wet season by the IWCs in Ibadan and other cities earlier reviewed showed a clear disparity. While the daily volume of waste collected by IWCs in Cairo and Lahore in the wet season was more than that of Ibadan, lesser volume of waste was collected in Manilla (PCI, 2008; Slackman, 2009; Kamran et al. 2015). The factors that could account for this may be the level of organization of the IWCs in those cities, official policies on informal waste collection, access to capital for acquisition of modern waste collection equipment, patronage rate of the IWCs and income accruable from waste collection business.

The dry season data revealed that the amount of waste evacuated by each of the IWCs in a week ranged from $87 \mathrm{~kg}$ to $2,240 \mathrm{~kg}$. Some $(34.4 \%)$ of the sampled waste collectors evacuated between $87 \mathrm{~kg}$ and $125 \mathrm{~kg}$; some $(47.2 \%)$ evacuated between $125.1 \mathrm{~kg}$ and $135 \mathrm{~kg}$; and $10.8 \%$ evacuated between 135.1 and $170 \mathrm{~kg}$. Some $(15.4 \%)$ evacuated about $500 \mathrm{~kg}, 18.6 \%$ evacuated about $1,000 \mathrm{~kg}$, while some $(9 \%)$ evacuated about $1500 \mathrm{~kg}$. Some (3.4\%) IWCs evacuated above $2,000 \mathrm{~kg}$. Only one waste collector evacuated about 2,240 $\mathrm{kg}$ of refuse in a week.

Further analysis showed that the average daily collection rate by an informal waste collector was $203 \mathrm{~kg}$, while the weekly collection rate was $1,421 \mathrm{~kg}$. The average monthly collection rate stood at about $6,293 \mathrm{~kg}$, while about $75,516 \mathrm{~kg}$ of refuse was evacuated annually by an informal waste collector. Thus, considering the 253 informal waste collectors sampled, it is evident that an average of $51,359 \mathrm{~kg}$ (51 tons) of waste was evacuated daily; weekly collection rate stood at $359,513 \mathrm{~kg}$ (359 tons); $1,592,129 \mathrm{~kg}$ (1,592 tons) was collected monthly; while $19,105,548 \mathrm{~kg}(19,105$ tons) of waste was collected in a year (see Table 2). These collection rates, when applied to the 506 IWCs enumerated in the study area, showed that the informal waste sector was responsible for evacuating during the dry season about $102,718 \mathrm{~kg}$ (102 tons) daily, $719,026 \mathrm{~kg}$ (719 tons) weekly, 3,184,258 $\mathrm{kg}$ (3,184 tons) monthly, and 38,211,096 kg (3,821 tons) yearly.

Just like in the wet season, there was also a clear disparity in the volume of waste collected in the dry season in Ibadan from other cities reviewed (PCI, 2008; Slackman, 2009; Kamran et al., 2015). The higher volume of waste collected by the IWCs in the wet season in Ibadan conforms to the pattern observed in other cities reviewed.

As shown in Table 2, an annual evacuation rate of 23,999,580 $\mathrm{kg}$ was recorded in the wet season, against $19,105,548 \mathrm{~kg}$ in the dry season with the mean collection rate of $21,552,564 \mathrm{~kg}$ per annum. The computed ANOVA $(F=19.08$ at $p=0.05)$ established that variation in the volume of waste collected in the wet and the dry seasons was statistically significant. The higher volume of waste collected in the wet season might be as a result of the preponderance of high-density waste that usually characterize the season (Zurbrügg, 2003; Nabegu, 2010). The reduction in the volume of waste in the dry season might be attributed to the low agricultural residues in this season and the observed tendency of the city's residents to burn their waste (especially leaves, paper, textiles, vegetables, and maize husk) by taking advantage of the pervasive dryness in the dry season which favours waste burning. The tendency for the people to consume less food (particularly fruits and vegetables) owing to the reduced production of the fruits and vegetables in the dry season appears to be partly responsible for the reduction in the volume of waste during the dry season.

Table 2. Volume of waste evacuated by the informal collectors in the dry and the wet seasons

\begin{tabular}{lccccc}
\hline Period & Wet Season & \multicolumn{3}{c}{ Dry Season } & Mean \\
\cline { 2 - 5 } & $\begin{array}{l}\text { Evacuation/ } \\
\text { Collector }(\mathrm{kg})\end{array}$ & $\begin{array}{l}\text { Evacuation/ } \\
\text { All }(\mathrm{kg})\end{array}$ & $\begin{array}{l}\text { Evacuation/ } \\
\text { Collector }(\mathrm{kg})\end{array}$ & $\begin{array}{l}\text { Evacuation/ All } \\
(\mathrm{kg})\end{array}$ & $\begin{array}{l}\text { Collection Rate } \\
(\mathrm{kg})\end{array}$ \\
\hline Daily & 255 & 64,515 & 203 & 51,359 & 57,937 \\
Weekly & 1786 & 451,858 & 1,421 & 359,513 & 405,686 \\
Monthly & 7905 & $1,999,965$ & 6,293 & $1,592,129$ & $1,796,047$ \\
Yearly & 94860 & $23,999,580$ & 75,516 & $19,105,548$ & $21,552,564$ \\
\hline
\end{tabular}


A total of $60.1 \%$ of the sampled waste collectors claimed that patronage by clients was affected in both seasons, with the dry season being the period when patronage was usually at its lowest. This influenced the number of waste evacuation and disposal trips the waste collectors could make and, consequently, their income. About $40.6 \%$ of the waste collectors claimed that the number of waste evacuation and disposal trips they made per day dropped by twenty-five per cent, while $11.2 \%$ and $8.2 \%$ experienced drop in the number of waste evacuation and disposal trips by about fifty per cent and seventy-five per cent, respectively. A collector realized an average of \$500 per trip and collectors made an average of four trips per day (Wahab and Ola, 2016). This indicates that an average of 2000 was realizable per day by a collector. However, with the drop in the number of trips, these collectors could only make a daily average of $1500, \$ 1,000$ and $\$ 500$, with the $25 \%, 50 \%$ and $75 \%$ drop in number of daily collection trip, respectively ( $\$ 197=1$ USD).

The major effect of the wet season on informal waste collection was the inability to move freely from one house to another and to the waste dumpsites owing to poor road conditions, as stated by $40 \%$ of the sampled waste collectors. Potholes filled with murky water on the routes to the dumpsites as well as slippery unpaved roads within the neighbourhoods hampered smooth movement of the waste carts operated by the waste collectors. Also, $20.1 \%$ of the IWCs claimed that whenever rain was falling, it was virtually impossible to effect waste collection from clients because the waste collectors could not work in the rain and clients would equally not bring out their wastes in the falling rain. This limited the number of trips that could be made by the informal waste collectors. The implications are that less volume of waste could be collected per disposal (leaving the environment with high volume of uncollected waste) and less income could be realized by the IWCs. Waste disposal in the wet season was equally done with a bit of difficulty by the IWCs as $73.6 \%$ claimed that as a result of the poor state of the roads to their dumpsites, they spent longer time to dispose of their waste. This equally contributed to the reduction in the number of trips in the wet season and, by inference, their realised income.

\section{Conclusion and Recommendations}

It has been shown that variation existed in the types and volume of waste evacuated by the IWCs in the wet and the dry seasons, with maize husks and polythene being the dominant wastes in both seasons. While the average volume of waste collected by the IWCs in the wet season daily was $255 \mathrm{~kg}, 203 \mathrm{~kg}$ was evacuated daily in the dry season. With a waste collector making an average of four trips in the wet season and realizing about 2000 in a day ( $197=1$ USD), the reduction in the volume of waste in the dry season led to a drop in the number of trips and reduction in the income accruable from the waste collection business by about $25 \%$. The study concluded that, while the wet and the dry seasons affected the volume of waste collected and the income realised by the IWCs in Ibadan, their services for prompt and regular waste collection and disposal are continuously required and demanded by their clients across the seasons.

The problem of reduced patronage of IWCs in the dry season raises concerns about job security in the informal waste collection business. Considering the positive role the IWCs have been playing in waste management scheme of Ibadan, as alluded to by Wahab and Ola (2016), and the fact that the ability of the formal collection system to effect total evacuation of waste in the city in the nearest future is doubtful, efforts should be made to ensure that this group of informal waste workers are effectively kept in the waste management scheme of the city. Indeed, more people should be encouraged to join the business, especially given the high rate of unemployment in Nigeria as revealed by the National Bureau of Statistics (NBS) (NBS, 2017). This can be achieved by providing financial assistance to the waste collectors for the purpose of establishing small waste merchandising business (through which the IWCs can serve as middlemen between the waste scavengers and the formal and informal recyclers) during the period of low patronage. This assistance can come directly from government through the provision of interest-free loans. Alternatively, government can encourage non-governmental organizations (NGOs) whose goal is to empower people economically to do so.

To address the problem of reduced accessibility in the wet season, government or NGOs should assist the IWCs to acquire motorized carts (tricycles) for waste collection. This will facilitate more effective door-to-door collection of waste in both the wet and the dry seasons, facilitate movement of the waste to the approved dumpsites and also encourage the residents to promptly bring out their wastes for evacuation.

There is also the need for government, through community development associations, to sensitize the city's residents on the need to avoid burning of waste within and around their houses, along the local roads and inside drains or in open spaces within their neighbourhoods. In addition to constituting serious air pollution, with its attendant damaging effects on the public health, burning of waste contributes significantly to the depletion of the ozone layer and consequently leads to global warming. 


\section{Acknowledgement}

Authors sincerely acknowledge the informal waste collectors who gave their time to be interviewed. The incisive comments of Professors S. B. Agbola and M. K. C. Sridhar on the initial draft of the paper are also acknowledged.

\section{References}

Afolayan, A. A. (1994). Population. In M. O. Filani, F. O. Akintola, \& C. O. Ikporukpo (Eds.), Ibadan Region (pp. 123-144). Ibadan: Rex Charles.

Afon, A. O. (2007). Informal sector initiative in the primary sub-system of solid waste management in Lagos, Nigeria. Habitat International, 31(2), 193-204. https://doi.org/10.1016/j.habitatint.2007.02.007

Ayorinde, D., Sridhar, M. K. C., Wahab, B., Asamu, S., \& Tairu, T. (2010). Waste characterization in Ibadan. A report prepared for Oyo State Ministry of Environment and Water Resources/In Went.

Boldrin, A., \& Christensen, T. H. (2009). Seasonal generation and composition of garden waste in Aarhus. Waste Management, 30(4), 551-557. https://doi.org/10.1016/j.wasman.2009.11.031

Denafas, G., Zavarauskas, K., Martuzevicius, D., Vitkauskait, L., Ludwig, C. H., Hoffman, M., ... Horttanainen, M. (2010). Seasonal aspects of municipal solid waste generation and composition in East-European countries with respect to waste management system development. Proceedings Venice 2010, Third International Symposium on Energy from Biomass and Waste, Venice, Italy; 8-11 November.

Enete, I. (2010). Potential impacts of climate change on solid waste management in Nigeria. Mimeo. Department of Geography and Meteorology, Nnamadi Azikiwe University, Awka.

Fahmi, W. S., \& Keith, S. (2006). Cairo's Zabaleen garbage recyclers: Multi-nationals' take-over and state relocation plans. Habitat International, 30(4), 61-76. https://doi.org/10.1016/j.habitatint.2005.09.006

Federal Republic of Nigeria (FRN). (2007). 2006 Nigerian Population. Official Gazette No. 24, Vol. 94 of 15th May, 2007.

Few, R., Ahern, M., Mathies, F., \& Kovist, M. (2004). Floods, health and climate changes: A strategic review. Working paper No 63, Tyndall: Centre for Climate Change Research.

Gómez, G., Meneses, M., Ballinas, L., \& Castells, F. (2009). Seasonal characterization of municipal solid waste in the city of Chihuahua, Mexico. Waste Management, 29, 2018-2024. https://doi.org/10.1016/j.wasman.2009.02.006

Gutberlet, J. (2008). Empowering collective recycling initiatives: video documentation and action research with a recycling co-op in Brazil. Resources, Conservation and Recycling, 52, 659-670. https://doi.org/10.1016/j.resconrec.2007.08.006

Hammed, T. B., Sridhar, M. K. C., \& Wahab, B. (2016). Enhancing solid waste collection and transportation for sustainable development in the Ibadan Metropolis, Nigeria. European Journal of Research in Social Sciences, 4(7), 23-32.

IPCC. (2017). Meeting Report of the Intergovernmental Panel on Climate Change: Expert meeting on mitigation, sustainability and climate stabilization scenarios. [Shukla, P.R. J. Skea, R. van Diemen, K. Calvin, Christophersen, F. Creutzig, J. Fuglestvedt, E. Huntley, F. Lecocq, M. Pathak, J. Portugal-Pereira, J. Rogelj, J. Roy, J. Scull, R. Schaeffer, R. Slade, D. Ürge-Vorsatz, D. van Vuuren.]. IPCC Working Group III TechnicalSupport Unit, Imperial College London, London, the United Kingdom.Addis Ababa, Ethiopia, 26 - 28 April 2017.

Jerie, S., \& Tevera, D. (2014). Solid waste management practices in the informal sector of Gweru, Zimbabwe. Journal of Waste Management, 20(1), 1-7. https://doi.org/10.1155/2014/148248

Kamran, A., Chaudhry, M., \& Batoo, S. (2015). Effects of socio-economic status and seasonal variation on municipal solid waste composition: A baseline study for future planning and development. Environ Science Europe, 27(1), 16-25. https://doi.org/10.1186/s12302-015-0050-9

Kirchhoff, V. W. J. H., da Silva, I. M. O., \& Browell, E. V. (1990). Ozone measurements in Amazonia: Dry season versus wet season. J. Geophys. Res. 95, 16913-16926. https://doi.org/10.1029/JD095iD10p16913

Mclaren International Ltd. (1970). Master plans for waste disposal and drainage in Ibadan. Volumes IV and V, drainage and solid waste reports prepared for WHO/Federal Republic of Nigeria. 
Mshelia, A. D. (2015). Seasonal variations of household solid waste generation in Mubi, Nigeria. International Journal for Innovation Education and Research, 3(5), 115-124.

NBS. (2017). Unemployment/Under-employment report June 2017. Abuja: National Bureau of Statistics. Retrieved from www.nigerianstat.gov.ng/download/564

NPC. (2007). Population and housing census of the Federal Republic of Nigeria. Abuja: National Population Commission.

Oguntoyinbo, J. S. (1994). Climatic characteristics. In M. O. Filani, F. O. Akintola, \& C.O. Ikporukpo (Eds.), Ibadan Region (pp. 58-71). Ibadan: Rex Charles.

Ola, A. B. (2016). Informal waste collectors in municipal solid waste management in Ibadan. Unpublished Ph.D. Thesis, Department of Urban and Regional Planning, University of Ibadan, Nigeria.

Olujimi, J. A. B. (2007). Climate change and coastal settlement planning in Nigeria: A call for capacity building. Bulletin of Science Association of Nigeria, 28, 28-31.

Olujinmi, J. A. B. (2009). Evolving a planning strategy for managing urban sprawl in Nigeria. Journal of Human Ecology, 25(3), 94-106.

Oluwande, P. A. (1983). A guide to tropical environmental health and engineering. Ibadan: NISER.

Omigbodun, A. (2013). Climate, climate change, the dry and wet seasons in West Africa (2). The Vanguard, Feb. 27, 2013: Pp. 19-21. Retrieved from https://www.vanguardngr.com/climate-climate-change-the-dry-and-wet-seasons-in-west-africa-2

Oyo State Government (OYSG). (2011). Government of Oyo State report on the assessment of the 26th August 2011 flood disaster in Ibadan metropolis. Nigeria, Ibadan: Oyo State Task Force on Flood Prevention and Management in Ibadan.

Oyo State of Nigeria. (2013). Environmental (Sanitation and Wastes Control) Regulations, 2013. Oyo State of Nigeria Extraordinary Gazette No. 6, Vol. 38 of $20^{\text {th }}$ March, 2013. Ibadan: Oyo State Government Printing Press.

Oyo State Solid Waste Management Authority. (2012). Waste management in Oyo State, Ibadan: A Report from Oyo State Solid Waste Management Authority.

OYOWMA. (2013). Waste management in Oyo State. Ibadan: Oyo State Solid Waste Management Authority.

PAI Associates International. (1982). The state of the environment in Nigeria. Monograph series, (2), Federal Ministry of Housing and Environment, Lagos.

PCI. (2008). The study on solid waste management for Metro Manila in the Republic of the Philippines. Tokyo: Pacific Consultants International.

Rennell, T. (2007). It's dry season and elephants are desperately seeking water - but poachers lie in wait. Daily Mail. June 29, 2007.

Rhyner, C. R. (1992). Monthly variations in solid waste generation. Waste Management \& Research, 10, 67-71. https://doi.org/10.1016/0734-242X(92)90057-R

Slackman, M. (2009). Cleaning Cairo, but taking a livelihood. New York Times, 24 May, 2009.

Sridhar, M. K. C., Bammeke, A. O., \& Omishakin, M. A. (1985). A study on the characteristics of refuse in Ibadan, Nigeria. Waste Management and Research, 3, 191-201. https://doi.org/10.1177/0734242X8500300126

United Nations Environment Programme. (2010). Waste and climate change: Global trends and strategy framework. Osaka/Shiga: United Nations Environmental Programme Division of Technology, Industry and Economics, International Environmental Technology Centre. Retrieved March 5, 2018, from https://www.unep.or.jp/ietc/Publications/Waste\&ClimateChange

United States Environmental Protection Agency. (2012). Inventory of greenhouse gas emission and sinks. New York: United States Environmental Protection Agency.

United States Environmental Protection Agency. (2016). Climate change and municipal solid waste. New York: United States Environmental Protection Agency. Retrieved March 5, 2018, from https://archive.epa.gov/wastes/conserve/tools/payt/web/html/factfin.html

United States Environmental Protection Agency. (2017). Health and environmental effects of ozone layer 
depletion. New York: United States Environmental Protection Agency. Retrieved January 16, 2018, from https://www.epa.gov/ozone-layer-protection/health-and-environmental-effects-ozone-layer- depletion

Uwejamomere, T. (2003). Climate change in Nigeria: A communication guide. Ibadan: Nigerian Environmental Study / Action Team (NEST).

Wahab, B. (2009). Waste: A resource to combat climate change at the local level. A Commissioned Paper presented at a Workshop Marking the 2009 World Environment Day Organized by the Oyo State House Committee on Environmental Services, held at Plaza de Haruna, Oyo, June 4-5, 2009.

Wahab, B., \& Ola, A. B. (2016). The activities of informal waste collectors in municipal solid waste management in Ibadan, Nigeria. Journal of Environmental Design and Management, 8(1\&2), 80-91.

Zelalem, F. C. (2006). Controlling the informal sector: Solid waste collection and the Addis-Ababa city administration, 2003-2005. M.Phil. Thesis, Department of Geography, Faculty of Social Sciences and Technological Management, Norwegian University of Science and Technology Trondheim, Norway.

Zia, A., Batool, S. A., Chauhdry, M. N., \& Munir, S. (2017). Influence of income level and seasons on quantity and composition of municipal solid waste: A case study of the capital city of Pakistan. Sustainability, 9, 1-13. https://doi.org/10.3390/su9091568

Zurbrügg, C. (2003). Solid Waste Management in Developing Countries. EAWAG/SANDEC.

\section{Copyrights}

Copyright for this article is retained by the author(s), with first publication rights granted to the journal.

This is an open-access article distributed under the terms and conditions of the Creative Commons Attribution license (http://creativecommons.org/licenses/by/4.0/). 